\title{
E - LEARNING DURING COVID-19 - PERSPECTIVES OF ACADEMICS
IN A CRISIS
}

\author{
Remigio Chingara ${ }^{1+}$ \\ Piet Muparuri ${ }^{2}$ \\ Denias Muzenda
}

\author{
${ }^{1,2,3}$ Robert Mugabe School of Education, Department of Educational \\ Foundations, Great Zimbabwe University, Masvingo, Zimbabwe. \\ 'Email:rchingara@gzu.ac.zw Tel:263774693304. \\ Email: pmuparuri@gzu.ac.zw Tel:263775252460 \\ ${ }^{s}$ Email:dmuzenda@gzu.ac.zw Tel:263772748198
}

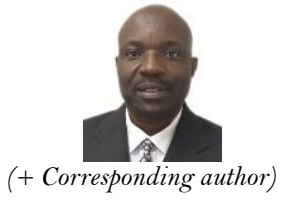

ABSTRACT
Article History

Received: 14 June 2021 Revised: 22 October 2021 Accepted: 19 November 2021 Published: 16 December 2021

\section{Keywords}

E- Learning

Covid 19

Perspectives

Academics

Crisis

Minimalist approach.

\begin{abstract}
This study offers insights into how e learning, can be sustained in universities in developing countries, using a minimalist approach, during a crisis such as Covid-19. The banning of face-to-face classroom teaching in Zimbabwean universities and the adoption of e learning motivated it. Whilst this was unexpected, unprepared for, with no precedent or blue print, very few studies appear to pay attention to the perspectives of the academics - the people who are doing the teaching of the students and from a developing country perspective. Apparently, those studies that have been conducted to date are largely quantitative and appear to concentrate on the perspectives of students. To address this gap, this study explores how academics at one school and in one department at a university in Masvingo province of Zimbabwe were teaching their students, the challenges they were encountering and the opportunities that were presenting themselves. The researchers adopted a qualitative research design, using a case study methodology, with a sample of eighteen (18) purposively selected participants (lecturers). The study used semi-structured interviews to collect data, using WhatsApp because of the imposed lockdown restrictions. Findings reveal that lecturers at this university were using only a few communication applications to teach their students. They cite challenges of the cost of connectivity as well as lack of administrative support as impediments to e learning and teaching. They however highlight training in e-learning technologies and provision of data as opportunities that have arisen.
\end{abstract}

Contribution/ Originality: The study documents the sustainability of e-learning in universities, in developing countries, using a minimalist approach, during a crisis such as Covid-19. It offers the perspectives of academics - the people who are doing the teaching of the students.

\section{INTRODUCTION}

The banning of face-to-face classroom teaching and the adoption of e- learning within a limited space of time because of the Covid-19 crisis remains arguably one of the biggest impacts on university education in Zimbabwe. The Corona virus (Covid-19) appeared very suddenly and therefore there could have been no planning for it. Equally, the emergence of covid-19 induced e learning in universities was unplanned, but a temporary response to a crisis. The shift from face to face tuition to e learning was very rapid, with no precedent or blueprint. This study is a response to what appears to be a dearth of studies that provide the perspectives of academics (lecturers) on their experiences of the covid-19 induced crisis, from a developing country perspective. More so, available studies appear to be largely quantitative. In addressing this gap, this study adopts an interpretative paradigm which is appropriate in this instance due to its ability to offer a view of given circumstances and to analyse these so as to present a 
perspective of how certain people understand their circumstances (Grossoehme, 2014). It explores the perspectives of academics at one school and in one department at a university in Masvingo province of Zimbabwe - a developing country, on e learning and teaching during the Covid19 pandemic. The purpose was to find out how they were teaching their students, the challenges they were encountering and the resultant opportunities.

The WHO (2020) outbreak, caused by severe acute respiratory syndrome coronavirus 2 (SARS-CoV-2), to be a pandemic on March 12, 2020.

On 30 March 2020, the United Nations Educational, Scientific and Cultural Organisation estimated that over 166 countries had implemented nationwide closures related to Covid-19, affecting 1.52 billion students, thus affecting over $87 \%$ of the world's student population. Around 429 universities from across the world closed and started conducting online classes and e-learning (UNESCO, 2020a). One of the biggest impacts on university education was that it was no longer possible to have face-to-face tuition, which is particularly suited for hands on work.

In response, university education in Zimbabwe went 100\% online. Universities had to come up with innovative responses meant to enable students to continue with their studies at home. Most universities settled for online teaching and learning. Transforming students' homes overnight into online educational environments became a valuable intervention to address the covid19 induced university closures. Likewise, lecturers assumed greater autonomy and teacher agency as they found teaching and learning solutions for their students struggling with challenges and changes.

Covid-19 made education to be a home based, technology enabled remote activity with zero physical contact (Harris, 2020). Transforming the traditional educational processes during crises into an electronic or online environment is a challenging task that requires lecturers in universities particularly in developing countries to establish the needed interaction with their students. The success of this shift requires lecturers to play a devoted role (Mackey, Gilmore, Dabner, Breeze, \& Buckley, 2012). They have to use the same features that make traditional classroom teaching successful to sustain online teaching.

Wolverton and Hollier (2019) postulate that guiding students through the online learning materials, responding to questions and maintaining live interaction among students is an approach that requires lecturers to be well prepared and have the experience and skills to accomplish this task. They claim that this is indeed a challenging task, which requires unlimited support from all stakeholders.

\section{LITERATURE REVIEW}

The literature review focuses on adding to the existing body of knowledge of literature on e learning by providing a comprehensive awareness on the challenges and opportunities with respect to Covid-19 as the world battles to eradicate the pandemic. E- Learning is a novel social process, which has been gathering momentum as the surrogate for customary face-to-face classroom, but viewed from the perspective of replacement processes branded as disruptive processes. It is the educational usage of technological devices, tools and the internet (Adedoyin \& Soykan, 2020). It is a form of teaching and learning situation in which the lecturer is at a distance from the student who uses some form of technology to access the learning materials and interact with the lecturer and other students. Some kind of support is provided to students (Rapanta, Botturi, Goodyear, Guàrdia, \& Koole, 2020). It relies entirely on technological devices and the internet (Heng \& Sol, 2020).

It is therefore undeniable that technology is the most pressing challenge to online learning if those involved in the process of teaching and learning are not digitally competent due to inexperience or insufficient training. Some typical technological issues cited include lack of knowledge of how to use applications, unstable/slow internet connection, outdated communication devices, and incompatible browsers (Heng \& Sol, 2020). Students from low socio-economic families are not able to afford broadband connection and pertinent devices such as computers/laptops or tablets to support their online learning (Heng \& Sol, 2020). 
Compatibility issue is another considerable challenge linked to e learning. While e learning appears to be applicable to particular academic disciplines, for example, social and linguistic studies, it might be inappropriate for practical disciplines such as sports, engineering, and medical studies because these disciplines require hands-on experiences as part of instructional activities (Adedoyin \& Soykan, 2020). In most developing countries, the digital infrastructure and resources are deficient, and this means teaching such practical disciplines online is undoubtedly a demanding challenge.

Recent research studies reveal the many other challenges on e learning during the covid-19 pandemic. For instance, e learning relies on an array of innovative tools to deliver learning materials and instruction. These include multimedia applications, social media tools, print materials, e-mail, the internet, computer software as well as audio and video-conferencing. These require internet connectivity. Maintaining instant connection becomes essential.

The adoption of e learning by universities the world over has brought along with it opportunities which ordinarily would have never come aboard under normal circumstances in a normal situation prior to the Covid-19 crisis. Internet service providers in some countries are now providing free broadband to institutions of learning. For example, in the USA, digital inclusion campaigner "Everyone On" has opened a search engine to assist people according to their ZIP code find low-cost internet bundle programs. Eastern Mediterranean University in conjunction with Turk Cell now provides free internet for their students and faculty (Adedoyin \& Soykan, 2020). From an African and developing country context, Vodacom in South Africa has launched special bundles and increased their zero-rated offer to all public institutions of learning for students and faculty of those institutions to have internet access.

\section{THEORETICAL FRAMEWORK}

The Technology- Organisation- Environment framework and the minimalist approach to e learning anchor the study. The Technology-Organisation-Environment framework theorises that technological adoption decision making is influenced by three principal contexts namely, technological, organisational and environmental (Luhamya, Bakkabulindi, \& Muyinda, 2017). The internal and external technologies that are relevant to the organisation and include both equipment and processes make up the technological context. Phones are a basic tool for both students and lecturers to stay in touch. Landline phones, e-mail, pagers, cell phones and short message services (SMS) require specific-software program to enable communication between the students and lecturers.

This suggests that technological applications, internet connectivity, communication devices, and browsers (Heng \& Sol, 2020) are all part of the technological context. Adoption of e learning is therefore dependent on these technologies and their relative advantage and compatibility. The organisational context is defined as the characteristics and resources of the organisation such as managerial support, organisational culture and size, communication processes and the amount of resources available to the organisation (Luhamya et al., 2017). The environmental context is the setting in which the organisation conducts its business. In the context of this study, the environmental context includes the Covid -19 context as mentioned in the background to the study.

This theory helps to enumerate the different factors that are relevant in various adoption contexts. This effectively makes it easy for one to identify challenges and opportunities in each context.

Minimalism anchors the minimalist approach, which consists of on line teaching and learning that includes only that which provides significant and demonstrable benefits to a student's course (Wolverton \& Hollier, 2019). It advocates for the use of only a limited amount of online resources and has been proven to foster creative behaviour (Ohly \& Fritz, 2010; Sonenshein, 2017). Studies indicate that abundant resources can cause organizations to struggle with creativity and lead to wasteful spending (Wolverton \& Hollier, 2019). However, providing only a limited amount of resources can foster creative behaviours (Ohly \& Fritz, 2010; Sonenshein, 2017) and allow for experimentation and learning (Sonenshein, 2017). The intention is not to imply that investment of resources is 
unnecessary. Instead, by adopting a minimalist approach, an institution can become more intentionally resourceful; seeking to achieve its goals with the resources it already possess more than it seeks additional resources, which it assumes will improve e learning.

While e learning does indeed need resources, the question is whether increasing them will bring positive results in universities. Adopting this approach is an attempt at making students and lecturers become more intentionally resourceful by using what they already possess than to seek additional resources, which they assume will improve online teaching and learning. Therefore, instead of merely increasing the number of technologies or training courses to encourage universities to teach online, focus should be on identifying essential desired resources, simplifying their offering, and directing resources to those essential areas.

Three essential components for online teaching and learning in a minimised way are required (Wolverton \& Hollier, 2019). The first fundamental requirement is the availability of a reliable internet connection. Secondly, laptops and cell phones are basic hardware tools for students and lecturers to stay in touch. Thirdly, specificsoftware applications are necessary to enable communication between lecturers and students.

The availability of a reliable internet connection is always fundamental to the use technology in educational contexts. Internet connectivity is available in most parts of Zimbabwe and along with it instant communication capabilities. According to the World Bank, access to a mobile phone or internet at home for young adults (Percentages 15-34) in Zimbabwe was reported at 80.39 \% in 2014 (World Bank Education, 2020). These statistics suggest that Zimbabwean university students who happen to fall between the said age group have the capacity for on line learning.

SMS are an available option for lecturers to communicate with students. Instant messaging (IM) allows students to ask questions during the learning process (Hrastinski, Edman, Andersson, Kawnine, \& Soames, 2014). Students whose university provided an internal SMS tended to participate and ask more questions during and after lessons (Scornavacca, Huff, \& Marshall, 2009). Other researchers have reported that the use of IM as a communication tool for faculty and students promotes student learning (Smit, 2012), active learning (Cifuentes \& Lents, 2011), informal communication between students (Cifuentes \& Lents, 2011; Smit, 2012), in-person interaction between students and faculty related to course content (Cifuentes \& Lents, 2011), a sense of belonging and community (Doering, Cynthia, George, \& Nichols-Besel, 2008; Sweeny, 2010), the breakdown of social barriers between teachers and students (Doering et al., 2008) and students' attentiveness and serious attitudes toward assignments (Sweeny, 2010).

WhatsApp messenger is another alternative tool for communication. This cross-platform, mobile messaging application enables users to exchange messages, phone calls, images, videos and audio using the same data plan as for e-mails and web browsing (Whatsapp, 2016). Church and De-Oliveira (2013) found that users adopt WhatsApp as their main communication channel rather than other platforms due to its immediacy, cost effectiveness, the desire to be a part of a trend and the constant interaction with friends and family. WhatsApp also enables users to send an unlimited number of messages and simultaneously conduct conversations with many friends. WhatsApp provides a free solution for students and teachers to communicate during disasters; teachers can create a WhatsApp group for classes and notify them of any updates or news.

The minimalist approach has been applied elsewhere across disciplines i.e. in art (Kim \& Kim, 2016), Legal studies (Shah, 2016), human resource management (Lorange, 2006), and architecture (Croaker \& Nicholson, 2016). Findings within management literature demonstrate significant implications related to resourcefulness within organisations. It would be interesting to find out how universities in Zimbabwe have adopted e- learning in response to Covid-19 induced e-learning considering that they are entrenched in an African context where there are inadequate resources unlike in the first world countries where there are abundant resources (Wolverton \& Hollier, 2019). 


\section{METHODOLOGY}

\subsection{Research Design}

The study used the interpretative paradigm. It was selected because of its ability to put forward a view of a situation, analyse it and give insight into the way in which a particular group of people make sense of or experience it Grossoehme (2014). Its greatest strength is the wealth and deepness of investigations and descriptions it yields. According to interpretivists' views, theory can only be produced and understood from the perspective of the people who stay and work in a particular society or organisation (Hatch \& Cunliffe, 2012). The interpretivist approach therefore guided this study in analysing the theme "Perspectives of academics in a crisis". The paradigm was suitable for this research as it studies human action in its normal reality. Academics (lecturers) shared their experiences on the covid-19 induced crisis in their natural setting and environment and the existing reality socially created. The paradigm therefore helped to interpret their understanding of the challenges they were experiencing as well as the opportunities that have arisen as result of the adoption of e- learning in their university.

The research study used the qualitative research design which Grossoehme (2014) defines as "a systematic collection, organisation and interpretation of textual material derived from talk or conversation." The study utilised the case study as its research method. Nieuwenhuis (2012) describes a case study as "a systematic inquiry into an event or a set of related events which aim to describe and explain the phenomenon of interest. The phenomenon of interest in this study is how academics (lecturers) at one university in Masvingo province of Zimbabwe are teaching their students during the covid-19 induced crisis, the challenges they are encountering and the resultant opportunities. The case study offers a multi- perspective analysis in which the researcher considers not just the voice and perspective of one or two participants in a situation, but also the views of other relevant groups of actors and the interaction between them.

\subsection{Population and Sample}

The study took place at a university located in the city of Masvingo in Zimbabwe. Of the seven schools found within the university, the study focused on one school only- the school of Education owing to its proximity with the researchers. The school has six departments. From these, the researchers purposefully selected the Department of Educational Foundations, owing to its proximity with the researchers at the time the research. The Department has six (6) sections.

The population of the study was therefore all the academics in the Department of Educational Foundations with thirty-seven (37) lecturers. The researchers used purposive sampling to select participants according to the following criteria i.e. participants had to be the chair of the department, section coordinator; senior lecturer or lecturer in each section subject to their availability on WhatsApp at the time the interviews are done via the WhatsApp platform. Nieuwenhuis (2012) describes purposive sampling as the process used to select participants because of some defining characteristic that makes them the holders of the data needed for the study.

The choice of WhatsApp was because it enables users to send an unlimited number of messages and simultaneously conduct conversations, thereby providing a free solution for academics and students to communicate during a Covid-19 induced total shut down, as was the case. The researchers found WhatsApp to be convenient owing to its cost effectiveness and voice recording capabilities. Overall, a section provided three participants. The overall sample was 18 participants. The purpose of the sample selection was not to compare the perspectives of the lecturers in the different sections of the department but to provide their experiences on e- learning during covid-19, its challenges and the opportunities thereof.

\subsection{Data Collection Instruments and Methods}

The study's instrument was the interview guide. An interview guide is a necessary part for conducting interviews. It comprises a list of questions that the researchers want to ask during the interview (Kajornboon, 
2005). According to McNamara (2009), the advantage of using interview guides lies in their ability to enable the researchers to collect the same information from each participant. This enables the researchers to remain focused and still exercise the freedom and flexibility to get information from participants. The researchers remain in control of the interview (Turner, 2010). This instrument is best suited for semi-structured interviews which Corbetta (2003) describes as the sort of interviews that allow the researcher to arrange the questions to be asked according to his own judgement. These allow for supplementary and unexpected questions. Taking notes or recording the interviews on tape document the interviews hence the use of WhatsApp. This sort of interview allows the researcher to further probe for the participants' views. Probing allows the researchers to investigate new avenues that were not originally thought out (Gray, 2004).

The advantages of semi-structured interviews lie in their ability to allow the researcher to solicit and investigate profoundly into the particular circumstances (Turner, 2010). These advantages necessitate that the researcher investigates deeply and not rely on the interview guide only. The researchers can therefore clarify or ask questions in another way if the participants are not clear about them.

The researchers used semi-structured interviews with open-ended questions to collect data from the participants. The following research questions guided this research:

- How would you describe your experiences of the challenges of e learning during the covid 19 crisis?

- How would you describe the opportunities that have arisen because of e learning during the covid19 crisis?

Participation was voluntary. Participants were encouraged to answer as honestly as possible and that their answers would remain confidential.

Participants took part in semi- structured interviews using WhatsApp because of the Covid-19 induced total shut down in Zimbabwe, which made the use of any other methods such as focus groups or observation difficult or materially impossible. The interviews took place synchronously with the recording. The researchers used pseudonyms to protect the participants' identities (e.g. sections were referred to as A, B, C, D, E, and F). Participants assumed the names participant from section A, participant from section B, participant from section C whichever the case was. The researchers used the voice recording function of WhatsApp to ask questions. Participants would then answer back using the same. The interviews took place while participants were at their homes. The interviews lasted approximately 20 minutes per participant. In the context of this study, the researchers spent up to two weeks collecting data from the academics. Responses to the interviews were analysed using the qualitative data analysis software programme ATLAS.ti. This was very helpful in doing initial coding (open coding). The researchers moved to the next phase of the data analysis process were the codes are organised or related codes combined into categories. Through Atlas ti, each category got a label or identifying name, using its own descriptive phrases or words from the text to establish a category. In the end, two categories emergedchallenges and opportunities. Essential insights that emerged from the data through coding and categorisation were included. The next step was to bring order and structure into the categories through themes. One theme emergedPerspectives of academics in a crisis. The theme was then analysed to reveal the true meaning of the data to derive conclusions that would form the basis of new knowledge or support existing knowledge.

\section{RESULTS AND DISCUSSION}

Three (3) participants from each section participated: the Departmental Chair or section coordinator, senior lecturer and lecturer. Eighteen (18) participants took part in the study, including the Departmental chair that doubled up as the section coordinator in one section. 
Table-1. Gender of Participants.

\begin{tabular}{l|c|c|c}
\hline Designation & Female & Male & Total \\
\hline Departmental Chair & 0 & 1 & 1 \\
\hline Section Coordinators & 2 & 4 & 6 \\
\hline Senior lecturers & 3 & 3 & 6 \\
\hline Lecturers & 3 & 2 & 5 \\
\hline Total & 8 & 10 & 18 \\
\hline
\end{tabular}

Table 1 above indicates the Gender of participants in this study.

Table 1 above indicates that Two (2) out of six (6) section coordinators were female. Four (4) were male. Three (3) out of six (6) senior lecturers were female. Three (3) were male. Three (3) lecturers were female. Two (2) were male. The only departmental chair in the study was male. Of the eighteen (18) participants in the study, eight (8) were female and ten (10) were male. These results suggest that there is a gender balance in this study.

Table 2 below indicates the ages of the participants in this study.

Table-2. Age of Participants

\begin{tabular}{c|c|c|c|c}
\hline Section & Departmental Chair & Section Coordinator & Senior Lecturer & Lecturer \\
\hline A & 44 & 37 & 51 & 39 \\
\hline B & 0 & 54 & 57 & 33 \\
\hline C & 0 & 55 & 55 & 0 \\
\hline D & 0 & 38 & 54 & 43 \\
\hline E & 0 & 48 & 60 & 41 \\
\hline F & 0 & 53 & 58 & 54 \\
\hline
\end{tabular}

Table 2 above indicates that ten (10) of the participants were in their fifties and above. Only four (4) are in their forties and four are in their thirties. The table also indicates that most of the senior lecturers are in their fifties and above. These results suggest that the participants in this study were quite mature when considering their ages.

Table-3. Professional Experience and Qualifications of the participants.

\begin{tabular}{l|l|l|l}
\hline Section & Designation & Professional Experience & Highest Qualification \\
\hline A & Section Coordinator & 2 & Master's in Education \\
\hline A & Senior Lecturer & 13 & PhD \\
\hline A & Lecturer & 15 & Master's in Education \\
\hline B & Section Coordinator & 9 & Associate Professor \\
\hline B & Senior Lecturer & 11 & PhD \\
\hline B & Lecturer & 14 & Master's in Education \\
\hline C & Section Coordinator & 12 & PhD \\
\hline C & Senior Lecturer & 12 & PhD \\
\hline D & Departmental Chair & 15 & PhD \\
\hline D & Section Coordinator & 13 & PhD \\
\hline D & Senior Lecturer & 11 & PhD \\
\hline E & Lecturer & 17 & Master's in Education \\
\hline E & Section Coordinator & 13 & PhD \\
\hline E & Senior Lecturer & 11 & PhD \\
\hline F & Lecturer & 9 & Master's in Education \\
\hline F & Section Coordinator & 16 & PhD \\
\hline F & Senior Lecturer & 14 & PhD \\
\hline
\end{tabular}

Table 3 above indicates the professional experience and qualifications of the participants in this study.

The table above shows that, at the time of the study, fifteen (15) of the participants had been in university service as lectures or senior lectures for more than 10 years. Only three had been in the service for less than ten (10) 
years. Most of the participants in the study had PhDs. Only one five (5) participants had masters degrees. This suggests that the participants had the craft literacy and competence to provide credible views of their experiences of the challenges and opportunities of e learning during the covid 19 crisis.

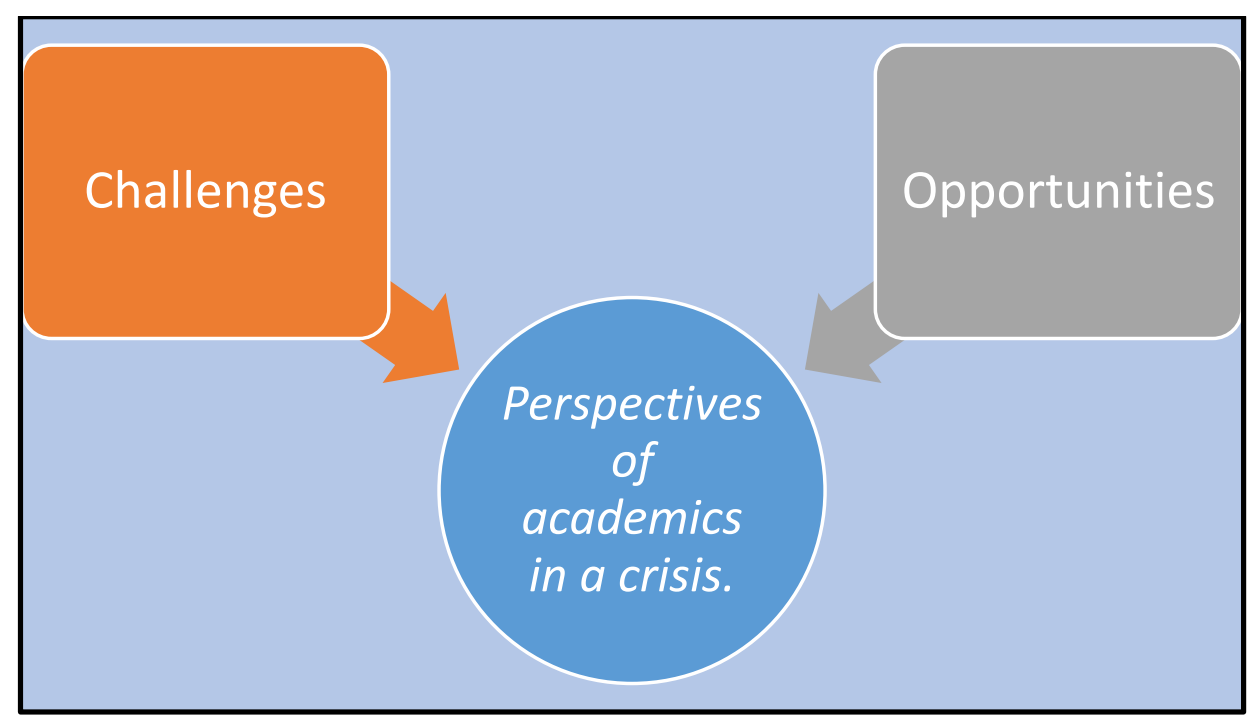

Figure-1. Categories and Theme.

Figure 1 indicates the categories and theme of the study.

Figure 1 above shows that there are two categories in this study namely "challenges" and "opportunities" which converge into one theme namely "perspectives of academics in a crisis" which will be discussed next. The theme reveals the perspectives of lecturers on their experiences of the challenges and opportunities.

The criteria for selecting participants in this study was availability (Accessibility). Their views, as will be indicated in subsequent discussions, were similar. This suggests that the participants had similar views on the challenges they were facing as well as the opportunities that presented themselves regardless of the differences in their age, gender, qualifications, professional experiences and designation.

\subsection{Theme: Perspectives of Academics in a Crisis}

The theme "perspectives of academics in a crisis" reveals the views of academics on challenges of e learning during the covid 19 crisis as well as the opportunities that arose as a result. It is in this context; the findings as presented under this theme established that there are challenges with e learning in a Covid induced crisis. The theme also provided an explanation on the opportunities that have arisen as a result. Two research questions addressed this theme:

- How would you describe your experiences of the challenges of e learning during the covid 19 crisis?

The presentation of results under this research question comes in concurrently with the discussion.

All participants interviewed in the study revealed that they experienced some challenges with e learning during the Covid-19 induced total shut down in Zimbabwe. For instance, one of the participants from Section A had this to say:

The university is insisting that I use Google classroom for teaching my students during this lock down. I am not yet fully conversant with this application and my students complain about it. The workshop I attended on this application has not managed to equip me fully on how to use it to interact with my students. I have resorted to WhatsApp and E-Mail.

A participant from Section B had this to say:

Both my Masters and Undergraduate students are comfortable with the WhatsApp platform and e-mail when compared to the Google Classroom platform. I have challenges with Google classroom in the form of its cost. I have 
to have internet access when using it and this is very costly for me. I am encouraging students to use WhatsApp, which is much cheaper, and user friendly.

Another participant from Section A had this to say:

I have challenges in accessing Wi-Fi. Most of my students are having the same challenge even though some managed to join Google classroom meaning they will not be active. In fact, 141 students out of 341 of my conventional students have joined Google classroom. We resorted to the WhatsApp platform where I have almost 98\% of the students participating.

A participant from Section $\mathrm{F}$ went on to say:

Look here. My computer is just like a refrigerator. It cannot operate without power. The battery is dead. I can only operate when there is power. Most of the time, we do not have electricity in the area where I stay. I cannot therefore use my laptop. Besides, most of my students have financial challenges when it comes to Wi-Fi and data bundles; they are utilising the WhatsApp platform, which is cost effective and user friendly.

One participant from Section C said:

My laptop is an old model. I cannot use most of the applications I am supposed to use on this computer because it is an old model. I can only send and /or access my emails on this computer.

The chair of the department who was also a participant had the following to say:

The statistics I have so far indicate that 737 students out of 2457 are on Google classroom; 756 students out of 2457 students are using e-mail. 2300 students out of 2457 are actively using the WhatsApp platform. Only 157 students are not on any e-learning platform. This suggests that the majority of our students find the WhatsApp platform convenient. We are therefore encouraging our lecturers to allow students to use whatever mode of communication favourable to them.

One participant from section D gave a very revealing comment when he said:

I have resorted to the WhatsApp and e-mail platforms because my students are not getting any technical help for them to access Google classroom from the IT department because of the lockdown.

The other participant from Section B weighed in and said:

Students are finding it difficult to join Google classroom because of lack of technical know how to do so even though they underwent training. Those who have joined it are citing the financial costs in terms of Wi-Fi or data bundles. This also applies to lecturers. Some students are in remote areas where connectivity is a challenge. WhatsApp is relatively affordable and the best alternative available.

The participant from Section D had this to say:

All my students are on WhatsApp and it is almost 100\%. However, my students have data, network and cost challenges. Some have to walk some distance to some specific spots to access network, which is a bit difficult in a lockdown situation. This makes communicating with them a challenge.

The participant from Section E had the following to say;

Most students were affected by the change in their emails hence they are not comfortable with Google classroom. They also cite challenges of the cost of connectivity. We seem to make progress via group chats on WhatsApp.

The other participant from Section $\mathrm{E}$ had this to say:

Rural based students are struggling with connectivity and cost factors. One student had no cell phone for 4 months due to the cost of the hardware. I have since advised my students to share hardware although this could promote plagiarism. I however advise my students that I do have an anti-plagiarism software that detect copying and pasting and this has acted as a deterrent.

The participant from Section C went on to say:

Some students failed to join Google classroom. I used the invite option which some joined successfully. Others had challenges of accessing the class. I suggest that there be more demos for both students and lecturers. 
An analysis of the participants' responses provides a clear picture of e learning during Covid-19 from the perspectives of academics (Lecturers). All participants (Sections A, B, C, D, E and F) confirmed that they experienced challenges with e learning during Covid-19. They cited inability to use the Google classroom platform (Sections A, C and D); Lack of access to Wi-Fi (Section A, D and F); cost of connectivity challenges (Section B, D, E and $\mathrm{F}$ ); hardware challenges (Section $\mathrm{C}, \mathrm{E}$ and $\mathrm{F}$ ), power challenges (Section $\mathrm{F}$ ) and lack of technical support from the ICT department (Section D). These results testify to the sudden and unplanned nature of the response to the Covid-19 crisis and are consistent with findings by Adedoyin and Soykan (2020) as well as Heng and Sol (2020).

As can be deduced from this study, there is evidence to suggest that the technological, organisational and environmental contexts (Luhamya et al., 2017) were not taken into consideration; ostensibly because of the sudden nature of the Covid-19 crisis. Where they appear to have been considerations (Participant from Section A), this was not done adequately enough to allow the academics to apply their knowledge on what had been learnt (Google Classroom).

Some kind of support is required for students to successfully adopt e-learning (Rapanta et al., 2020) and yet in this instance both students and lecturers complained about lack of such (Section D). This finding simply confirms that the Corona virus (Covid-19) indeed appeared very suddenly and therefore there could have been no planning for it. This also confirms that the introduction of e learning was indeed very rapid. Heng and Sol (2020) maintain that e learning relies entirely on technological devices and the internet and yet findings in this study confirm that participants experienced challenges of lack of access to Wi-Fi (Section A, D and F); cost of connectivity challenges (Section B, D, E and F); hardware challenges (Section C, E and F) and power challenges (Section F).

These results cement the already undeniable fact that technology is the most pressing challenge to online learning particularly if those involved in the process of teaching and learning are not digitally competent due to inexperience or insufficient training. These results also bring out issues to do with inclusivity and equity inherent in education, which profoundly affects learners in terms of differential access to the internet and digital learning platforms. This is aptly summarised by the participant from section E who talks about rural based students struggling with connectivity and cost factors.

The chair of the department provides compelling statistics of the kind of applications in use during e learning. WhatsApp tops the list followed by the e-mail and then Google classroom. This finding appears to support the suitability of the minimalist approach to e learning (Wolverton \& Hollier, 2019). All participants from sections A to F confirmed that they were using WhatsApp, suggesting that WhatsApp was their preferred means of communication. This is not surprising because according to Church and De-Oliveira (2013), users adopt WhatsApp as their main communication channel rather than other platforms due to its immediacy and cost effectiveness. This suggests that instead of merely increasing the number of applications to encourage e- learning, the focus should be on identifying essential desired communication tools (applications), simplifying them and putting them to use. Focus should be on how to use the applications for effective and meaningful learning.

\subsection{Opportunities Brought By E-Learning during a Crisis}

- How would you describe the opportunities that have arisen because of e learning during the covid19 crisis?

All participants interviewed in the study revealed that there were opportunities that have arisen because of e learning. One participant from Section $\mathrm{F}$ had this to say:

We have received training on e learning particularly Google classroom. I can now interact with my students
through Google classroom. The university has deposited money for data bundles into our bank accounts in order to
facilitate e learning. Each member can purchase at least 20GB for e-learning purposes. The university pledged to
continue reviewing the situation and to make the necessary adjustments where necessary. This will in calculate a
culture of e teaching in us since we are receiving this kind of support. I only wish the university could sustain it.

The Participant from Section D went on to say: 
The university has asked members of staff who need laptops/tablets and modems to submit their names to the departmental Chair.

The participant from Section A had this to say:

The library has availed a link from where students and lecturers can now have access to it from wherever they are.

An analysis of the participants' responses provides a clear picture of the opportunities that arose because of e learning during the covid-19 crisis. The opportunities cited in the study are training in Google classroom (Section F); receiving data bundles, (Section F), a pledge by the university to buy computers for its academics (Section D) and a library link for students to access the library from wherever they are.

The banning of face-to-face classroom teaching and the adoption of e- learning within a limited space of time because of the Covid-19 crisis has brought in a quick digital transformation on university education in Zimbabwe. Results from this study suggest that the opportunity offered by the crisis of getting everybody to make use of elearning tools and applications was quite an ultimate accomplishment. This is aptly summarised by one participant from section $\mathrm{F}$ who said that they have received training on e learning and can now interact with students on Google classroom. The pledge by the university to make provision for laptops/tablets (Section D) is testimony to the digital transformation that has hit Zimbabwean universities.

Perhaps one major opportunity stands out. It is the provision of data through the help of internet service providers in Zimbabwe. This move is consistent with what internet service providers in some countries are now doing; i.e. providing free broadband to institutions of learning. For example, in the USA, digital inclusion campaigner in the USA, Turk cell in Turkey and Vodacom in South Africa are assisting learning institutions with internet services at reduced cost or for free. Similarly, Zimbabwe has Econet and Net one, which are doing the same thing.

\section{CONCLUSIONS}

To date, few studies have systematically explored the perspectives of academics on e- learning during Covid-19. This study therefore provided their perspectives on challenges and opportunities to e learning because of the Covid19 induced crisis. The challenges cited ranged from inability to use the Google classroom platform, Lack of access to $\mathrm{Wi}-\mathrm{Fi}$, cost of connectivity challenges, hardware challenges, power challenges and lack of technical support. The opportunities cited were training, provision of data, a pledge on hardware support and unfettered access to the library.

The main finding of this study is how e learning in universities in developing countries is taking place using a minimalist approach. Focus should therefore be on identifying essential desired communication tools (applications), simplifying them and putting them to use. The study recommends that more funding be availed to provide training for academics (university lecturers) to adapt to both offline and online learning environments. In addition, students must have access to computers, laptops or tablets and a reliable internet connection so that they can access resources and continue learning at home during the academic disruptions caused by the pandemics such as Covid19.

Funding: This study received no specific financial support.

Competing Interests: The authors declare that they have no competing interests.

Acknowledgement: All authors contributed equally to the conception and design of the study.

\section{REFERENCES}

Adedoyin, O. B., \& Soykan, E. (2020). Covid-19 pandemic and online learning: The challenges and opportunities. Interactive Learning Environments, 1-13. Available at: https://doi.org/10.1080/10494820.2020.1813180.

Church, K., \& De-Oliveira, R. (2013). What's up with whatsApp? Comparing mobile instant messaging behaviors with traditional SMS. Mobile HCI-Collaboration and Communication, Munich, August 30. 
Cifuentes, O. E., \& Lents, N. H. (2011). Increasing student-teacher interactions at an urban commuter cam-pus through instant messaging and online office hours. Electronic Journal of Science Education 14(1), 1-11.

Corbetta, P. (2003). Social research theory, methods and techniques. London: SAGE Publications.

Croaker, T., \& Nicholson, M. (2016). Inside out (online), Green: Sustainable Architecture and Landscape Design, 51, 40-46.

Doering, A., Cynthia, L., George, V., \& Nichols-Besel, K. (2008). Preservice teachers' perceptions of instant messaging in two educational contexts. Journal of Computing in Teacher Education, 25(1), 5-12.

Gray, D. E. (2004). Doing research in the real world. London: SAGE Publications.

Grossoehme, D. H. (2014). Overview of qualitative research. Journal of Health Care Chaplaincy, 20(3), 109-122.

Harris, A. (2020). Leading a school during lockdown. Journal of Professional Capital and Community, 5(3/4), 32 1-326. Available at: https://doi.org/10.1108/JPCC-06-2020-0045.

Hatch, M. J., \& Cunliffe, A. L. (2012). Organisation theory: Modern, symbolic and and postmodern perspectives (pp. 1-55). England: Oxford University Press.

Heng, K., \& Sol, K. (2020). Online learning during covid-19: Key challenges and suggestions to enhance effectiveness. Cambodian Education Forum. Retrieved from: https://cambodianeducationforum.wordpress.com/2020/12/o8/online.

Hrastinski, S., Edman, A., Andersson, F., Kawnine, T., \& Soames, C.-A. (2014). Informal math coaching by instant messaging: Two case studies of how university students coach K-12 students. Interactive Learning Environments, 22(1), 84-96. Available at: https://doi.org/10.1080/10494820.2011.641682.

Kajornboon, A. B. (2005). Using Interviews as research Instruments. Australia: Language Institute: Chulalongkorn University.

Kim, C., \& Kim, H.-g. (2016). 'Conveyance': Kinetic art reflected in the formative characteristics of Minimalism. TECHART: Journal of Arts and Imaging Science, 3(4), 1-3.

Lorange, P. (2006). A performance-based, minimalist human resource management approach in business schools. Human Resource Management, 45(4), 649-658.

Luhamya, A. L., Bakkabulindi, F. E. K., \& Muyinda, P. B. (2017). Integration of ICT in teaching and learning: A review of theories, Makerere. Journal of Higher Education, 9(1), 21 - 36.

Mackey, J., Gilmore, F., Dabner, N., Breeze, D., \& Buckley, P. (2012). Blended learning for academic resilience in times of disaster or crisis. Journal of Online Learning and Teaching, 8(2), 122-132.

McNamara, C. (2009). General guidelines for conducting interviews. Retrieved from: http://managementhelp.org/evaluatn/intrview.htm.

Nieuwenhuis, J. (2012). Introducing qualitative research. In K. Maree (Ed.), First steps in research (pp. 47-66). Pretoria: Van Schaik.

Ohly, S., \& Fritz, C. (2010). Work characteristics, challenge appraisal, creativity, and proactive behavior: A multi-level study. Journal of Organizational Behavior, 31(4), 543-565. Available at: https://doi.org/10.1002/job.633.

Rapanta, C., Botturi, L., Goodyear, P., Guàrdia, L., \& Koole, M. (2020). Online university teaching during and after the Covid-19 crisis: Refocusing teacher presence and learning activity. Postdigital Science and Education, 2(3), 923-945. Available at: https://doi.org/10.1007/s42438-020-00155-y.

Scornavacca, E., Huff, S., \& Marshall, S. (2009). Mobile phones in the classroom: if you can't beat them, join them. Communications of the ACM, 52(4), 142-146. Available at: https://doi.org/10.1145/1498765.1498803.

Shah, R. (2016). Morgan's minimalism: an epistemic approach to contract law. Critical Review, 28(3-4), 356-379. Available at: https://doi.org/10.1080/08913811.2016.1245824.

Smit, I. (2012). Whatsapp with BlackBerry: can messengers (BBM) beMXit? Paper presented at the 14th Annual Conference on World Wide Web Applications, Cape Peninsula University of Technology, Cape Town, September 22.

Sonenshein, S. (2017). Stretch: Unlock the power of less - and achieve more than you ever imagined. New York: Harper Business.

Sweeny, S. M. (2010). Writing for the instant messaging and text messaging generation: Using new literacies to support writing instruction. Journal of Adolescent \& Adult Literacy, 54(2), 12 1-130. Available at: https://doi.org/10.1598/jaal.54.2.4. 
Turner, I. D. W. (2010). Qualitative interview design: A practical guide for novice investigators. The Qualitative Report, 15(3), 754-760.

UNESCO. (2020a). COVID-19 education response, preparing the reopening of schools. Paris: UNESCO.

Whatsapp. (2016). About Whatsapp. Retrieved from: www.unisdr.org. [Accessed February 12, 2014].

WHO. (2020). Coronavirus disease 2019 (COVID-19) situation report- 62. August 2020. Retrieved from; https://www.who.int/emergencies/diseases/novel-coronavirus-2019/situation-reports.

Wolverton, C. C., \& Hollier, B. N. G. (2019). A minimalist design for distance learning. International Journal of Educational Management, 33(7), 1457-1465. Available at: https://doi.org/10.1108/ijem-09-2017-0237.

World Bank Education. (2020). Guidance note: Remote learning and COVID-19. Retrieved from: http://documents.worldbank.org/curated/en/531681585957264427. [Accessed 3 May 2020]. 